BIOMEDICAL AND BIOSOCIAL ANTHROPOLOGY
Official Journal of the International Academy
of Integrative Anthropology
journal homepage: http://bba-journal.com

\title{
Features cephalometric indicators in boys and girls of various craniotypes with physiological occlusion
}

Gunas I.V. ${ }^{1}$, Marchenko A.V. ${ }^{2}$, Kyrychenko Yu.V. ${ }^{1}$ Anisimov E.M. ${ }^{3}$

${ }^{1}$ National Pirogov Memorial Medical University, Vinnytsya, Ukraine

${ }^{2}$ The Higher State Educational Establishment of Ukraine "Ukrainian Medical Stomatological Academy", Poltava, Ukraine

${ }^{3}$ Bogomolets National Medical University, Kyiv, Ukraine

ARTICLE INFO
Received: 12 December, 2017
Accepted: 26 January, 2018

UDC: $616.314-084$

\section{CORRESPONDING AUTOR}

e-mail: freekozak1@gmail.com Gunas V.I.
The study of the features of the general shape and size of the cerebral and facial skull is a necessary link in the system of complex morphometric evaluation of the structures of the tooth-jaw system. The purpose of the study is to establish the features of cephalometric indices in young men and girls of different craniotypes with physiological bite. Cephalometric study consisted of determination of parameters of the cerebral and facial sections of the head of 44 boys and 50 girls with physiological bite. The form of the head was determined by the formula $m s \_m s$ * $100 / g \_o p$, where $m s \_m s$ is the largest head width (occipital diameter); g_op - the largest length of the head (distance from glabella to opisthokranion). Up to a value of 75.9 men attributed to dolichocephals; 76,0-80,9 - to mesocephals; 81,0-85,4 - to brachycephals. Statistical processing of the obtained results was carried out using the statistical software package "Statistica 6.1" using nonparametric methods. The reliability of the difference between independent quantitative values was determined using the Man-Whitney $U$-criterion. Found that dolichocephalic and hiperbrahitsefalichna shape of the head are the most rare: among boys 6 dolichocephals found, 16 mesocephals, 19 brachycephals, 3 hyperbrachycephals; and among girls - 1 dolichocephals, 16 mesocephals, 26 brachycephals, 7 hyperbrachycephals. When comparing craniotypological differences in cephalometric indices, it was found that the sagittal arc, the greatest length of the head, the height of the red lumbar lobe in the mesocephals is significantly greater or tends to be larger than brachycephals. Conversely, the largest and smallest head width, face width, outer-orbital width, inter-orbital width, width of the mandible, the distance from the auricular point to the angle of the mandible in the mesocephals is significantly lower or tends to lower values compared to brachycephals. The value of cephalometric parameters in young men is significantly higher than that of girls, which is confirmed by the results of studies on the general tendency of preferences of cephalometric linear dimensions in males. We did not detect significant sexual differences for only the average face width and forehead height. As a result of the studies conducted, regardless of sex, there are significantly higher longitudinal and smaller transverse dimensions of the facial and cerebellum of the skull in the mesocephals than brachycephals.

Keywords: cephalometry, practically healthy boys and girls, craniotype, physiological bite

\section{Introduction}

At present, great importance for dentistry is given to the study of the features of the general shape and size of the skull, which, like all skeletal bones, are subject, within certain limits, to fluctuations in individuals of the same sex, age and odontotype $[6,15]$.

In order to assess the proportionality of individual head sizes to dimensional characteristics of the patient's teeth, the physician first of all should pay attention to such constitutional features as the type of skull and face. Objective morphometric evaluation of the structures of the tooth-jaw system of patients, taking into account differentiating constitutional features, is a necessary link in the system of 
complex clinical examination in the course of medical and restoration work $[13,18]$.

Conducting regulated screening studies is as successful as possible with the consideration of non-average values that characterize the parameters of the brain and the facial part of the skull, and in assessing the individual and craniotypological range of variability of anatomical signs in conditions of normal development of bite $[3,17]$. Estimating cephalometric indices is normal, especially important, in addition to their craniotypological features, to make corrections to the age differences and to choose the optimal age for the study group [4, 26]. By this age, most experts consider the youth to be the most stable in terms of skull shape and cephalometric parameters than in other age periods $[1,21]$.

There is a certain lack of knowledge of the variant anatomy of the cerebral and facial skull in juvenile persons. This period of life is important because the constant bite finally develops, which is associated with the eruption of the third permanent molars [23, 26].

Thus, adolescents continue and have an intensive process of forming skull structures, dental arches and teeth, namely: the width and depth of the dental arches, the length of the upper and lower jaws, the angles of inclination to the plane of the outer base of the skull, the plane of the upper and lower jaws, the occlusion plane, angle of inclination to the Frankfurt horizontal plane of the upper jaw, angle of inclination to the occlusal plane of the upper and lower jaw plane, length of the anterior section of the outer skull base, full height of the face $[19,24]$.

If you take the older age group, then in studies of skull shape and size of its departments in people aged 20 to 55 there is talk of changes during adolescence, which occurred most rapidly during the 2 nd and $3 r d$ decades of life, but did not stop later [8, 25].

Thus, carrying out of a complex morpho-geometric study of cephalometric indices in juvenile persons with orthognathic bite of a homogeneous ethno-territorial group corresponds to the demands of modern orthodontics, normal anatomy, anthropology and ethnic odontology, which, due to multivariate analysis of the received information, will significantly improve the quality of the medical-diagnostic process.

The purpose of our study was to establish the features of cephalometric indices in young men and girls of different craniotypes with physiological bite.

\section{Materials and methods}

The cephalometric study consisted of determining the parameters of the cerebral and facial sections of the head with the help of a large sliding compass with a scale in the real size of the Martin system and soft centimeter ribbon. Cephalometric studies were conducted taking into account the generally accepted recommendations and anatomical points $[2,5]$.

The shape of the head was determined by the formula ms_ms*100/g_op, where ms_ms is the largest head width (occipital diameter); g_op - the largest length of the head (distance from glabella to opisthokranion) [2]. Up to a value of 75.9 men attributed to dolichocephalic; $76,0-80,9$ - to mesocephalic; 81,0-85,4 - to brachycephalic.

Statistical processing of the obtained results was carried out using the statistical software package "Statistica 6.1" using nonparametric methods. The reliability of the difference between independent quantitative values was determined using the Man-Whitney U-criterion.

\section{Results}

As a result of our research, we established a percentile scale (25.0 percentl and 75.0 percentl for different age groups) of cephalometric indices in boys and girls with orthognathic bite in both general groups and in distribution to different craniotypes (Table 1).

It is established that the magnitude of the sagittal arc has a pronounced tendency $(p=0.053)$ to the higher values in the mesocephalic males compared to the brachycephals males.

The value of the greatest length of the head in the men mesocephalic is significantly $(p<0.01)$ greater than brachycephals males. In girls of general groups and mesocephalic, this size is significantly ( $p<0.05$ in both cases) greater than brachycephals in girls.

The size of the largest head width in men mesocephalic is significantly $(p<0.01)$ less than brachycephals males. In girls of general groups and mesocephalic, this size is significantly ( $p<0.01$ in both cases) less than in brachycephals girls.

The size of the smallest head width in young men mesocephalic is significantly $(p<0.05)$ less than in brachycephals males. In mesocephalic girls, this size has a slight tendency $(p=0.073)$ to lower values compared to girls brachycephals.

The size of the facial width in the mesocephalic girls is significantly $(p<0.05)$ smaller than that of brachycephals girls.

The size of the external-orbital width in the men mesocephalic is significantly lower $(p<0.01)$, and in young men of the general group tends to $(p=0.066)$ lesser values than brachycephals males.

The size of the inter-orbital width in the mesocephalic males is significantly $(p<0.05)$ less than in brachycephals males.

The size of the height of the red lumbar lobe in mesocephalic girls is significantly higher $(p<0.05)$, and in girls of the general group has a pronounced tendency $(p=$ 0.055 ) to greater values than in girls brachycephals.

The size of the mandibular width in the mesocephalic girls is significantly lower $(p<0.05)$ compared with girls brachycephals.

The magnitude of the distance from the auricular point to the angle of the mandible in the young mesocephalic men is significantly $(p<0,05)$ lower than in brachycephals males. 
Gunas I.V., Marchenko A.V., Kyrychenko Yu.V.' Anisimov E.M.

Table 1. The percentile range of cephalometric indices in young men and women with orthognathic bite ( $\mathrm{mm}$ ).

\begin{tabular}{|c|c|c|c|c|c|c|c|}
\hline \multirow{3}{*}{ Indexes } & \multirow{3}{*}{ Sex } & \multicolumn{6}{|c|}{ Groups } \\
\hline & & \multicolumn{2}{|c|}{ total } & \multicolumn{2}{|c|}{ mesocephalic } & \multicolumn{2}{|c|}{ brachicephalic } \\
\hline & & 25,0 th percentl & 75,0 th percentl & 25,0 th percentl & 75,0 th percentl & 25,0 th percentl & 75,0 th percentl \\
\hline \multirow{2}{*}{ DUG_G_OP } & B & 563 & 580 & 568 & 580 & 560 & 580 \\
\hline & $\mathrm{G}$ & 545 & 560 & 545 & 560 & 545 & 560 \\
\hline \multirow{2}{*}{ DUG_AU_AU } & $B$ & 365 & 375 & 365 & 377,5 & 360 & 380 \\
\hline & $\mathrm{G}$ & 340 & 360 & 340 & 350 & 340 & 360 \\
\hline \multirow{2}{*}{ DUGS_G_OP } & B & 333 & 356 & 338 & 360 & 330 & 350 \\
\hline & $\mathrm{G}$ & 320 & 340 & 322,5 & 340 & 320 & 340 \\
\hline \multirow{2}{*}{ V_GOL } & $B$ & 136 & 142 & 137 & 142,5 & 136 & 141 \\
\hline & $\mathrm{G}$ & 130 & 135 & 130 & 133,5 & 129 & 135 \\
\hline \multirow{2}{*}{ G_OP } & $\mathrm{B}$ & 189 & 198 & 192 & 200 & 187 & 193 \\
\hline & $\mathrm{G}$ & 180 & 187 & 183,5 & 190 & 181 & 185 \\
\hline \multirow{2}{*}{ EU_EU } & $B$ & 152 & 158 & 151,5 & 156 & 155 & 161 \\
\hline & $\mathrm{G}$ & 148 & 154 & 146 & 150 & 149 & 155 \\
\hline \multirow{2}{*}{ FMT_FMT } & $B$ & 111 & 116 & 110,5 & 115 & 112 & 120 \\
\hline & $G$ & 108 & 112 & 106 & 110,5 & 109 & 113 \\
\hline \multirow{2}{*}{ ZM_ZM } & $B$ & 108 & 117 & 110 & 115 & 106 & 120 \\
\hline & $\mathrm{G}$ & 107 & 115 & 105 & 115 & 107 & 116 \\
\hline \multirow{2}{*}{$Z Y \_Y Y$} & $B$ & 137 & 144 & 136,5 & 142 & 139 & 147 \\
\hline & $\mathrm{G}$ & 131 & 136 & 130 & 135,5 & 134 & 138 \\
\hline \multirow{2}{*}{ EK_EK } & B & 100 & 105 & 100 & 103,5 & 103 & 109 \\
\hline & $G$ & 98 & 102 & 98 & 102 & 98 & 102 \\
\hline \multirow{2}{*}{ MF_MF } & B & 23 & 25 & 23 & 24 & 23 & 27 \\
\hline & $G$ & 22 & 24 & 22,5 & 25 & 22 & 24 \\
\hline \multirow{2}{*}{ AL_AL } & $B$ & 31 & 34 & 31 & 34,5 & 31 & 33 \\
\hline & $\mathrm{G}$ & 29 & 32 & 30 & 32,5 & 29 & 33 \\
\hline \multirow{2}{*}{ CHI_CHI } & $B$ & 50 & 54 & 50 & 53,5 & 51 & 55 \\
\hline & $\mathrm{G}$ & 49 & 52 & 49 & 52 & 49 & 52 \\
\hline \multirow{2}{*}{$A U \_A U$} & B & 123 & 132 & 123 & 128,5 & 125 & 135 \\
\hline & $\mathrm{G}$ & 118 & 126 & 117 & 125,5 & 118 & 127 \\
\hline \multirow{2}{*}{ TR_N } & $B$ & 63 & 73 & 64 & 73 & 61 & 74 \\
\hline & $\mathrm{G}$ & 62 & 75 & 62 & 74,5 & 62 & 73 \\
\hline \multirow{2}{*}{ TR_GN } & $B$ & 174 & 184 & 176,5 & 185 & 173 & 183 \\
\hline & $\mathrm{G}$ & 168 & 180 & 170 & 179,5 & 166 & 178 \\
\hline \multirow{2}{*}{ N_PRN } & B & 47 & 50 & 46 & 52 & 48 & 50 \\
\hline & $\mathrm{G}$ & 43 & 47 & 42,5 & 47,5 & 43 & 46 \\
\hline $\mathrm{NCN}$ & $B$ & 50 & 53 & 50,5 & 54,5 & 50 & 53 \\
\hline IN_UT & $G$ & 45 & 50 & 42,5 & 49,5 & 45 & 50 \\
\hline CM PRP & $B$ & 27 & 30 & 27 & 30 & 28 & 30 \\
\hline Siv_r TIV & $\mathrm{G}$ & 25 & 27 & 25 & 27,5 & 26 & 28 \\
\hline N STO & B & 69 & 73 & 69 & 74,5 & 69 & 73 \\
\hline N_SIO & $\mathrm{G}$ & 65 & 69 & 64,5 & 69,5 & 65 & 69 \\
\hline$N 1$ & $B$ & 70 & 76 & 69 & 75,5 & 70 & 77 \\
\hline N_t & $\mathrm{G}$ & 68 & 72 & 67,5 & 72,5 & 68 & 72 \\
\hline
\end{tabular}




\section{Continuation of Table 1 .}

\begin{tabular}{|c|c|c|c|c|c|c|c|}
\hline \multirow{3}{*}{ Indexes } & \multirow{3}{*}{ Sex } & \multicolumn{6}{|c|}{ Groups } \\
\hline & & \multicolumn{2}{|c|}{ total } & \multicolumn{2}{|c|}{ mesocephalic } & \multicolumn{2}{|c|}{ brachicephalic } \\
\hline & & 25,0 th percentl & 75,0 th percentl & 25,0 th percentl & 75,0 th percentl & 25,0 th percentl & 75,0 th percentl \\
\hline \multirow{2}{*}{ N_PR } & $\mathrm{B}$ & 65 & 69 & 64,5 & 68,5 & 65 & 71 \\
\hline & $\mathrm{G}$ & 61 & 65 & 60 & 65,5 & 61 & 66 \\
\hline \multirow{2}{*}{ N_GN } & $B$ & 110 & 117 & 110 & 118 & 112 & 120 \\
\hline & $\mathrm{G}$ & 105 & 110 & 105,5 & 112,5 & 105 & 110 \\
\hline \multirow{2}{*}{ SN_STO } & B & 18 & 21 & 18 & 21 & 17 & 21 \\
\hline & $\mathrm{G}$ & 17 & 20 & 17 & 20 & 16 & 20 \\
\hline \multirow{2}{*}{ STO_SPM } & $\mathrm{B}$ & 21 & 24 & 22 & 24 & 21 & 25 \\
\hline & $G$ & 20 & 22 & 20 & 23 & 20 & 22 \\
\hline \multirow{2}{*}{ STO_GN } & $\mathrm{B}$ & 46 & 49 & 46 & 48,5 & 46 & 50 \\
\hline & $\mathrm{G}$ & 42 & 45 & 42,5 & 47,5 & 43 & 45 \\
\hline \multirow{2}{*}{ LS_L } & $\mathrm{B}$ & 18 & 20 & 18 & 21 & 18 & 20 \\
\hline & $\mathrm{G}$ & 16 & 20 & 18 & 20,5 & 16 & 18 \\
\hline \multirow{2}{*}{ GO_GO } & $B$ & 105 & 110 & 106 & 110,5 & 104 & 113 \\
\hline & $\mathrm{G}$ & 100 & 104 & 96,5 & 102,5 & 100 & 108 \\
\hline \multirow{2}{*}{ GO_GN } & B & 95 & 100 & 96 & 100 & 95 & 101 \\
\hline & $\mathrm{G}$ & 89 & 94 & 89 & 93,5 & 88 & 94 \\
\hline \multirow{2}{*}{ AU_GN } & B & 130 & 137 & 128,5 & 136 & 131 & 139 \\
\hline & G & 126 & 131 & 125 & 132 & 126 & 131 \\
\hline \multirow{2}{*}{ AU_GO } & B & 59 & 67 & 56,5 & 63 & 60 & 68 \\
\hline & $G$ & 55 & 61 & 56 & 64,5 & 56 & 61 \\
\hline \multirow{2}{*}{ AU_GL } & B & 127 & 130 & 127 & 130 & 126 & 130 \\
\hline & $G$ & 120 & 123 & 119,5 & 124 & 119 & 122 \\
\hline \multirow{2}{*}{ AU_N } & B & 118 & 123 & 117,5 & 123 & 118 & 123 \\
\hline & $\mathrm{G}$ & 114 & 117 & 115 & 117,5 & 114 & 117 \\
\hline \multirow{2}{*}{ AU_SN } & $B$ & 118 & 123 & 115,5 & 121,5 & 119 & 124 \\
\hline & $G$ & 112 & 116 & 113 & 119 & 112 & 116 \\
\hline \multirow{2}{*}{ AU_I } & B & 118 & 123 & 117 & 122,5 & 118 & 124 \\
\hline & $\mathrm{G}$ & 114 & 119 & 114 & 119,5 & 114 & 119 \\
\hline
\end{tabular}

Notes: B - boys; G - girls; 25,0th - 75,0th percentl - percentile sampling rate; DUG G OP - the largest girth of the head due to glabella and inion; DUG_AU_AU - transverse arc measured by the ribbon from the right goose point to the left; DUGS_G_OP - sagittal arc measured by the tape from the glabella to the occipital point; V_GOL - projection distance from the vertex and the upper edge of the auditory opening; G_OP - the largest length of the head, this is the distance from the glabella to opisthokranion; EU_EU - maximum head width (occipital diameter); FMT_FMT - the smallest head width (front diameter); ZM_ZM - average width of the face, is the distance between the zygomaxillary points; ZY_ZY - the width of the face, it is the distance between the cheekbone points; EK EK - outer-orbital width (bi-orbital width), this is the direct dimension between the outer angles of the eye gaps; MF_MF - inter-orbital width (front interstitial width), is a straight line distance between the inner angles of the eye pits; AL_AL - width of the base of the nose (distance between the points); $\mathrm{CHI} C \mathrm{CHI}$ - the width of the mouth gap; AU_AU - ear diameter (biauricular width); TR_N - height of the forehead, is the direct distance between the points of the trichion and nasion; TR_GN - physiological length of the face, is the distance from the trichion (line of hair growth) to gnathion; N PRN is the length of the nose; this is the distance between the nasion and the pronation; N_SN - height of the nose, is the distance between the upper-nose and sub-nose points; SN_PRN is the depth of the nose, this is the distance between the sub-nose point and the nose; N STO - height of the upper face, is the distance from the nasal to the mouth point; N I - the distance between the nasion and the inter-cutter point; N_PR is the distance between the nasion and the prosthion; N_GN - morphological length of the face, is the direct distance from the nasion to the gnathion; SN_STO - height of the upper lip, is the distance from the sub-nose point to the stomach; STO_SPM is the height of the lower lip, is the distance from stomion to supramental; STO_GN - height of the lower part of the face, this distance from the mouth point to the pinnacle; LS_LI - height of the red border of the lips; GO_GO - width of the lower jaw, or width between the angles of the lower jaw; GO_GN - body length of the mandible (averaged); AU_GN - distance from the auricular point to the chin (averaged); AU_GO - distance from the auricular point to the angle of the mandible (averaged); $A U$ _GL - distance from auricular point to glabella (averaged); AU_N - distance from auricular point to nasion (averaged); AU_SN - distance from auricular point to subnasion (averaged); AU_I - distance from the auricular point to the inter-cutter point (averaged). 
Significant manifestations of sexual dimorphism are established for cephalometric indices (higher in boys), which are more commonly observed among boys and girls of general groups and brachycephals than between mesocephals.

\section{Discussion}

The results of the study [10] showed that dolichocephalic and hyperbrachycephals facial forms of the head are the most rare. According to our data, 6 dolichocephals, 16 mesocephalic, 19 brachycephals, 3 hyperbrachycephals were found among the young men; and among girls - 1 dolichocephalic, 16 mesothephal, 26 brachycephals, 7 hyperbrachycephals.

This is consistent with the results of similar studies [7, 22]. Taking into account the distribution, only boys and girls are included mesocephalic and brachycephals for further analysis in different cranio-groups.

A number of authors established the predominance of longitudinal dimensions between the craniometric points of the skull in the dolichocephalic and transverse in brachycephals and hyperbrachycephals [30, 32].

In children, adolescents, young adults and adults, the upper limit of the range of values of the longitudinal dimensions of the skull in the mesocephalic is shifted towards the dolichocephalic, and the upper limit of the range of values of transverse sizes of the skull in brachycephalic - to hyperbrachycephalic [9, 11, 29]. Therefore, the study of the specifics of cephalometric indices in boys and girls of these two craniotypes is permissible only for the estimation of patterns of morphogenesis, typical and individual variability of the skull, and the study of their relationship with the private constitution of a person.

In the majority of our established or tendentious discrepancies in mesocephalic boys and girls, in comparison with brachycephals, larger values of the part of the longitudinal (sagittal arc, the largest length of the head), altitudes (the height of the red lobes of the lips), and smaller values of the part of the transverse (the largest and the smallest width head, face width, outer-orbital width, interorbital width, width of the lower jaw and distance from the auricular point to the angle of the mandible) of the size of the cranial and gnathic part of the skull.

Between the physical development of the body and the degree of development of soft tissues and the structure of the

\section{References}

[1] Abolhasanzadeh, A., \& Farahani, M. R. (2003). Standarded international classification of head shapes of 22-24 years old in Tehran. J. of Research in Medicine, 26, 281-285.

[2] Alexeev, V. P., \& Debets, G. F. (1964). Kraniometriya. Metodika antropologicheskih issledovaniy. M.: Nauka.

[3] Allanson, J. E., Cunniff, C., Hoyme, H. E., McGaughran, J., Muenke, M., \& Neri, G. (2009). Elements of morphology: standard terminology for the head and face. Am. J. Med. Genet., 149A(1), 6-28. doi: 10.1002/ajmg.a.32612.

[4] Arslan, S. G., Genç, C., Odabaş, B., \& Kama, J. D. (2008). Comparison of facial proportions and anthropometric norms facial skeleton in children and young men with orthognathic bite, there is a close relationship that reflects the relationship of "body-face". The literature deals with the adaptive (environmental) nature of such features as the width and protrusion of the nose, the thickness of the soft faces of the face, the thickness and width of the lips, the nature of the fatty and muscular formations in the pharynx and nasopharyngeal region, and finally the proportions of face $[14,22]$.

In the works of O. Zaichenko [31], M. L. Noback and K. Harvati [20], the absence of a proportional dependence of the soft tissue facet of the face on the form of the brain skull is proved. That is why our study found a small number of craniotypological differences in the size of the structures of the soft tissue part of the face.

The value of cephalometric parameters in young men is significantly higher than that of girls, which is confirmed by the results of studies on the general tendency of the advantages of cephalometric linear sizes in males $[12,16]$. We did not detect significant sexual differences for only the average face width and forehead height.

Consequently, despite the high level of development of modern neurosurgery and orthodontics, it is necessary to detail the parameters of bone and soft tissue construction of the cranial and gnathic part of the skull, based on the teaching of individual anatomical variability of $\mathrm{V}$. N. Shevkunenko $[27,28]$. At the same time, the refined characteristic of craniotypological and gender characteristics of cephalometric indices allows us to develop and apply in practice new plastic and reconstructive operations on the structures of the skull.

Prospects for further research are to conduct of multiple regression analysis, which will determine the characteristics of the characteristics of dental arches, depending on odontometric and cephalometric indices. This will allow for unfortunate errors in calculating and predicting the transversal size of jaws, sagittal characteristics of the dental arc, depending on odonto-cephalometric indices.

\section{Conclusions}

The results of the study substantiate the feasibility and necessity of identifying differences in cephalometric indices in individuals with different craniotypes. Established significantly larger longitudinal and smaller lateral dimensions of the facial and brain sections of the skull in mesocephals than brachycephals.

among Turkish young adults with different face types. Aesthetic Plast. Surg., 32(2), 234-242. doi:10.1007/ s00266-007-9049-y.

[5] Bunak, V. V. (1941). Antropometriya. Prakticheskiy kurs. M.: Uchpedgiz.

[6] Da Silva, M. B., \& Sant'Anna, E. F. (2013). The evolution of cephalometric diagnosis in orthodontics. Dental Press J. Orthod., 18, 3, 63-71. http://dx.doi.org/10.1590/S217694512013000300011.

[7] Evereklioglu, C. S., Doganay, H., Gunduz, A., Terkan, M., Balt, A., \& Cumurcu, T. (2006). Morphological Evaluation 
of Head and Face in 18-25 Years Old Women in Southeast of Iran. J. Med. Sci., 6(3), 400-404. doi: 10.3923/ jms.2006.400.404.

[8] Farishta, S., Varma, D. P., Reddy, K. S., Chandra, S., \& Nanda, Z. (2011). Cephalometric evaluation-based on Steiner's analysis on young adults of Chhattisgarh, India. J. Contemp. Dent. Pract., 12(3), 174-178.

[9] Franco, F. C. M., de Araujo, T. M., Vogel, C. J., \& Quint?o, C. C. A. (2013). Brachycephalic, dolichocephalic and mesocephalic: Is it appropriate to describe the face using skull patterns? Dental Press. J. Orthod., 18(3), 159-163. http:// dx.doi.org/10.1590/S2176-94512013000300025.

[10] Gunas, I. V., Shinkaruk-Dykovytska, M. M., Kotsyura, O. O., Orlovskiy, V. O., Dmytrenko, S. V., Shayuk, A. V., \& Glushak, A. A. (2017). Differences of craniotype distribution and types of face among apparently healthy men from different regions of Ukraine. Folia Morphol., 76(3), 473-477. doi: 10.5603/FM.a2017.0017.

[11] Hossain, Md. G., Sabiruzzaman, Md., Islam, S., Ohtsuki, F., \& Lestrel, P. E. (2010). Effect of craniofacial measures on the cephalic index of Japanese adult female students. Anthropological Science, 118(2), 117-121. doi: 10.1537/ ase.091022.

[12] Ilayperuma, I. (2011). Evaluation of Cephalic Indices: A Clue for Racial and Sex Diversity. Int. J. Morphol., 29(1), 112-117.

[13] Klingenberg, C. P. (2009). Morphometric integration and modularity in configurations of landmarks: tools for evaluating a priori hypotheses. Evol. Dev., 11, 405-421. doi: 10.1111/ j.1525-142X.2009.00347.x.

[14] Kondo, S., Wakatsuki, E., \& Shibagaki, H. A. (1999). Somatometric study of the head and face in Japanese adolescents. Okajimas Folia Anat. Jpn., 76, 179-185.

[15] Kumar, B. S., Shree, V. P., \& Revathi, P. (2009). Dentofacial cephalometric norms for Hyderabad population. J. Orofacial. Sci. 1(1), 7-13.

[16] Mahajan, A., Khurana, B. S., Seema, \& Singh, B. A. P. (2010). The study of cephalic index in Punjabi students. Journal of Punjab Academy of Forensic medicine and Toxicology, 10, 24-26.

[17] Mane, D. R., Kale, A. D., Bhai, M. B., \& Hallikerimath, S. (2010). Anthropometric and anthroposcopic analysis of different shapes of faces in group of Indian population: a pilot study. J. Forensic. Leg. Med., 17(8), 421-425. doi: 10.1016/ j.jflm.2010.09.001.

[18] Mitteroecker, P., \& Gunz, P. (2009). Advances in geometric morphometrics. Evol. Biol., 36, 235-247. https://doi.org/ 10.1007/s11692-009-9055-x.

[19] Muzurova, L. V., Rezugin, A. M., \& Konnov, V. V. (2007). Vozrastnaya $\mathrm{i}$ individualnaya izmenchivost verhney $\mathrm{i}$ nizhney chelyustey $u$ lits s ortognaticheskim prikusom. Saratovskiy nauchno-meditsinskiy zhurnal, 3(17), 34-36.

[20] Noback, M. L., \& Harvati, K. (2015) Covariation in the Human Masticatory Apparatus. The anatomical record, 298, 64-84. https://doi.org/10.1002/ar.23067.
[21] Oladipo, G. S., Olotu, J. E., \& Suleiman, Y. (2009). Anthropometric studies of cephalic indices of the Ogonis in Nigeria. Asian J. Med. Sci. , 1, 15-17.

[22] Reyes-Centeno, H., Ghirotto, S., Détroit, F., Grimaud-Hervé, D., Barbujani, G., \& Harvatia, K. (2014). Genomic and cranial phenotype data support multiple modern human dispersals from Africa and a southern route into Asia. Proc. Natl. Acad. Sci. USA, 111(20), 7248-7253. https://doi.org/10.1073/ pnas. 1323666111.

[23] Thilander, B. (2009). Dentoalveolar development in subjects with normal occlusion. A longitudinal study between the ages of 5 and 31 years. Eur. J. Orthod., 31(2), 109-120. doi: 10.1093/ejo/cjn124.

[24] Tikku, T., Khanna, R., Maurya, R. P., Verma, S. L., Srivastava, K., \& Kadu, M. (2014). Cephalometric norms for orthognathic surgery in North Indian population using Nemoceph software. J. Oral Biol. Craniofac. Res., 94-103. doi: 10.1016/j.jobcr.2014.07.004.

[25] Trivedi, K., Singh, S., Shivamurthy, D. M., Doshi, J., Shyagali, T., \& Patel, B. (2010). Analysis of cephalometrics for orthognathic surgery: determination of norms applicable to Rajasthani population. Natl. J. Maxillofac. Surg., 1(2), 102-107. doi: 10.4103/0975-5950.79209.

[26] Vojdani, Z., Bahmanpour, S., Momeni, S., Vasaghi, A., Yazdizadeh, A., Karamifar, A., ... Mokhtar, A. (2009). Cephalometry in 14-18 years old girls and boys of ShirazIran high school. Int. J. Morphol., 27, 101-104. doi: 10.4067/ S0717-95022009000100018.

[27] Vovk, Y. N., \& Bekov, D. B. (2001). Individualnaya anatomicheskaya izmen- chivost i anatomicheskaya norma stroeniya cheloveka. Problemi ekologichnoyi ta medichnoyi genetiki i klinichnoyi imunologiyi, 7(39), 81-89.

[28] Vovk, Y. N., \& Vovk, O. Y. (2016). Perspektivyi i novyie napravleniya ucheniya ob individualnoy anatomicheskoy izmenchivosti. Vestnik problem biologii i meditsinyi, 2, 1(128), 376-379.

[29] Vovk, O. Y. (2011). Kraniometricheskie osobennosti cherepa detey $v$ vozraste pervogo detstva (4-7 let). VIsnik problem blologiyi i meditsini, 2(2), 38-40.

[30] Yadav, A. O., Walia, C. S., Borle, R. M., Chaoji, K. H., Rajan, R., \& Datarkar, A. N. (2011). Cephalometric norms for Central Indianpopulation using Burstone and Legan analysis. Indian J. Dent. Res., 22(1), 28-33. doi: 10.4103/09709290.79970.

[31] Zaichenko, A. A. (2008). Constructional typology of human cerebral cranium. The theses are presented in the materials of XLVII Congress of Anthropological Society of Serbia with international participation, Kruševac (p. 96). Kruševac: [w.p.h].

[32] Zulkina, L. A. (2009). Osobennosti kranio-fatsialnogo kompleksa u zhiteley penzenskogo regiona. Tezisyi predstavlenyi $\vee$ mater. Vseross. nauchno-prakt. konf.: Sotsialnyie problemyi meditsinyi i ekologii cheloveka, Saratov (str. 407). Saratov: [b. i.].

\section{Гунас І.В., Марченко А.В., Кириченко Ю.В., Анісімов Є.М. ОСОБЛИВОСТІ КЕФАЛОМЕТРИЧНИХ ПОКАЗНИКІВ У ЮНАКІВ І ДІВЧАТ РІЗНИХ КРАНІОТИПІВ 13 ФІЗІОЛОГІЧНИМ ПРИКУСОМ}

Вивчення особливостей загальної форми і розмірів мозкового і лицьового черепа є необхідною ланкою в системі комплексної морфометричної оцінки структур зубо-щелепної системи. Мета дослідження - встановлення особливостей кефалометричних показників у юнаків і дівчат різних краніотипів із фізіологічним прикусом. Кефалометричне дослідження складалося з визначення параметрів мозкового та лицьового відділів голови 44 юнаків та 50 дівчат із фізіологічним прикусом. Форма голови визначалась за формулою ms_ms*100/g_op, де ms_ms - найбільша ширина голови (потиличний діаметр); g_op - найбільша довжина 
голови (відстань від глабелли до опістокраніон). При значенні до 75,9 чоловіків відносили до доліхоцефалів; 76,0-80,9 - до мезоцефалів; 81,0-85,4 - до брахіцефалів. Статистичну обробку отриманих результатів проводили за допомогою ліцензійного статистичного програмного пакету "Statistica 6.1" з використанням непараметричних методів. Достовірність різниці значень між незалежними кількісними величинами визначали за допомогою U-критерію Мана-Уітні. Встановлено, що доліхоцефалічна і гіпербрахіцефалічна форми голови є найбільш рідкісними: серед юнаків встановлено 6 доліхоцефалів, 16 мезоцефалів, 19 брахіцефалів, 3 гіпербрахіцефалів; а серед дівчат - 1 доліхоцефал, 16 мезоцефалів, 26 брахіцефалів, 7 гіпербрахіцефалів. При порівнянні краніотипологічних відмінностей кефалометричних показників встановлено, що сагітальна дуга, найбільша довжина голови, висота червоної кайми губ у мезоцефалів достовірно більша або має тенденції до більших значень порівняно із брахіцефалами. I, навпаки, найбільша і найменша ширина голови, ширина обличчя, зовнішньоочна ширина, міжочноямкова ширина, ширина нижньої щелепи, відстань від аурикулярної точки до кута нижньої щелепи у мезоцефалів достовірно менша або має тенденції до менших значень порівняно із брахіцефалами. Значення кефалометричних параметрів у юнаків достовірно більше, ніж у дівчат, що підтверджується результатами досліджень про загальну тенденцію переваги кефалометричних лінійних розмірів у чоловічої статі. Нами не виявлені істотні статеві відмінності лише для середньої ширини обличчя і висоти лоба. В результаті проведених досліджень не залежно від статі встановлені достовірно більші повздовжні та менші поперечні розміри лицевого та мозкового відділу черепа у мезоцефалів порівняно із брахіцефалами.

Ключові слова: кефалометрія, практично здорові юнаки і дівчата, краніотип, фізіологічний прикус.

Гунас И.В., Марченко А.В., Кириченко Ю.В., Анисимов Е.Н. ОСОБЕННОСТИ КЕФАЛОМЕТРИЧЕСКИХ ПОКАЗАТЕЛЕЙ У ЮНОШЕЙ И ДЕВУШЕК РАЗНЫХ КРАНИОТИПОВ С ФИЗИОЛОГИЧЕСКИМ ПРИКУСОМ

Изучение особенностей общей формы и размеров мозгового и лицевого черепа является необходимым звеном в системе комплексной морфометрической оценки структур зубочелюстной системы. Цель исследования - установление особенностей кефалометричних показателей у юношей и девушек разных краниотипив с физиологическим прикусом. Кефалометричне исследование состояло из определения параметров мозгового и лицевого отделов головы 44 юношей и 50 девушек с физиологическим прикусом. Форма головы определялась по формуле ms_ms*100/g_op, rде ms_ms наибольшая ширина головы (затылочный диаметр); g_op - наибольшая длина головы (расстояние от глабеллы до опистокранион). При значении до 75,9 мужчин относили к долихоцефалам; 76,0-80,9 - к мезоцефалам; 81, 0-85,4 - к брахицефалам. Статистическую обработку полученных результатов проводили с помощью лицензионного статистического программного пакета "Statistica 6.1" з использованием непараметрических методов. Достоверность различий значений между независимыми количественными величинами определяли с помощью U-критерия Мана-Уитни. Установлено, что долихоцефаличная и гипербрахицефаличная формы головы является наиболее редкими: среди юношей установлено 6 долихоцефалов, 16 мезоцефалов, 19 брахицефалов, 3 гипербрахицефалов; а среди девушек - 1 долихоцефал, 16 мезоцефалов, 26 брахицефалов, 7 гипербрахицефалов. При сравнении краниотипологических различий кефалометрических показателей установлено, что сагиттальная дуга, наибольшая длина головы, высота красной каймы губ у мезоцефалов достоверно большая или имеет тенденцию к большим значениям по сравнению с брахицефалами. И, наоборот, наибольшая и наименьшая ширина головы, ширина лица, внешнеглазная ширина, междуглазничная ширина, ширина нижней челюсти, расстояние от аурикулярной точки до угла нижней челюсти у мезоцефалов достоверно меньше или имеет тенденции $к$ меньшим значениям по сравнению с брахицефалами. Значение кефалометричних параметров у юношей достоверно больше, чем у девушек, что подтверждается результатами исследований об общей тенденции преимущества кефалометричних линейных размеров у мужского пола. Нами не обнаружены существенные половые различия только для средней ширины лица и высоты лба. В результате проведенных исследований независимо от пола установлены достоверно большие продольные и меньше поперечные размеры лицевого и мозгового отдела черепа у мезоцефалов по сравнению с брахицефалами.

Ключевые слова: кефалометрия, практически здоровые юноши и девушки, краниотип, физиологический прикус. 